\title{
The Role of Nursery Educators in the Promotion of Mental Health of Children from 0-18 Months
}

\author{
${ }^{1}$ M. C. Kupfer, ${ }^{2}$ M. E. Pesaro \\ ${ }^{1}$ University of São Paulo, ${ }^{2}$ Lugar de Vida Association
}

\begin{abstract}
Childcare in infancy has been proven to significantly reduce the incidence of mental disorders in childhood. Nursery educators must therefore be prepared to keep up with the psychic development of children under their care. The IRDI (Clinical Risk Indicators for Child Development) is a psychoanalytically-based instrument able to point out developmental problems in children from 0-18 months. This paper intends to present the initial results of a research project aimed at evaluating the IRDI methodology as a tool to promote mental health in the early stages of child development. The 31 IRDI risk indicators served as a guide for educators when following the psychic development of children under the supervision of psychoanalysts. The results of the first phase of the study showed that there was a change in the teachers' perception of childcare.
\end{abstract}

\section{Introduction}

The idea that scientific, economic and social efforts should concentrate on early childhood is nowadays no longer a novelty [1]. Economists and political scientists are unanimous in stating that investment in early childhood prevents great expenditures. A survey carried out by the InterAmerican Development Bank showed that for every US\$1 invested in public policies for early childhood, US\$7 are saved in the future. Another study carried out by the Institute of Applied Economic Research (Ipea) showed that pre-school education has visible short, medium and long term results, and that it is more significant for parents with low schooling [2].

However, this growing social awareness may not result in any significant improvement in children's psychosocial conditions in future if the psychic dimension conceived by psychoanalysis is not considered. The attention given to early childhood has focused on the guarantees of health and education for children from the beginning of their lives, but has not addressed their later mental health.
Concern for the future psychic development of today's children is not unfounded. In fact, there has been a significant increase in mental health disorders in childhood in current times. The epidemiological incidence and prevalence of developmental and mental health disorders in childhood are unknown in the majority of developing countries. Several epidemiological studies point to mental health disorder rates of $9-16 \%$ [3], [4].

On the other hand, research and publications in the last ten years have demonstrated that early psychoanalysis-based interventions can prevent long periods of suffering and treatment [5]; [6]; [7]. An early childhood professional who is well aware of the subjective life of a baby can become an agent of mental health promotion of great value. Thus, actions aimed at training and informing mental health professionals on development and especially on the subjective constitution of babies are of particular interest.

It is therefore imperative for human development that recent neurological findings be articulated with the contributions of psychoanalytical studies on the psychic constitution of babies [8] and with studies that confirm the importance of education in early childhood [9].

In Brazil, there have been efforts to improve the training of child educators so as to prepare them to widen their remit, by proposing to link education and care, but little attention has been paid to the aim of promoting mental health from early childhood [10].

The research here presented proposed to investigate a methodology able to guide teachers in the task of supporting and promoting mental health in nurseries. To this end, it sought out a trusted instrument for detecting risk in child development, initially validated for use by paediatricians in regular mother and baby appointments. It was then necessary to adapt this instrument for use by teachers in nurseries. We will now present this instrument, known as IRDI, and the adaptation of its methodology to nurseries. 


\section{The IRDI instrument}

The validation of the IRDI instrument was carried out by means of the IRDI research [11], conducted in the period from 2000 to 2008 by a group of researchers from the University of São Paulo, who developed a tool composed of 31 clinical indicators of psychic risk or developmental problems in children, noticeable in the first 18 months of a child's life.

The research was conducted by a team of specialists who came together at the Ministry for Health. It was financed as a Thematic Project of FAPESP (São Paulo Research Foundation) and carried out at the University of São Paulo Institute of Psychology.

\subsection{Theoretical underpinnings of the IRDI instrument}

Maturity, growth, and especially development depend on the processes of formation of psychic life, and are extremely sensitive to them. These processes operate under the authority of others who relate to the child and are responsible for his/her care and evolution.

Although unique, the construction of subjectivity depends on general actions that every caregiver is expected to perform in early childhood, without which this subjectivity runs the risk of not being created.

The 31 IRDI indicators were developed based on four theoretical axes. The outline of these axes was based on some of the main works of S. Freud (Freud, 1905/1996 [12]; Freud, 1920/1996 [13] and Freud, 1924/1996 [14]).

Axis 1 is called "subject assumption" (SA) and characterises the anticipation of the mother or caregiver of the presence of a psychic subject in the child, which, however, has not yet been constituted. This constitution depends exactly on the fact that this mother (or caregiver). This anticipation gives the child great pleasure, since it is accompanied by an expression of joy from the mother - words loaded with a pleasurable musicality, called "motherese" [15]; [16], and this will make the child strive to retribute to what was anticipated. In this attempt, the child will bring back the pleasure experienced at the time of the mother's anticipation - the frown, translated by the mother as a smile, will really become a smile. Thus, the subjectivity that had not yet been installed may be effectively built.

Axis 2, called the "establishment of demand" axis, (DE), describes the first involuntary responses that the child presents at birth, such as crying, are recorded, which will be recognized by the mother as a request made by the child to her. This recognition will allow for the construction of a demand - for psychoanalysis, always a demand for love - from this subject to all of those who he/she will relate to. This demand will be at the basis of all future activities of language and relationship with others.

The third axis, "presence/absence" (PA), characterises the mother's actions that make her alternately present and absent. The mother's absence will mark all human absence as an existential occurrence worthy of note, compelling the child to develop a subjective mechanism to symbolise it. The mother's presence will be not only physical, but mainly symbolic. Between the child's demand and the experience of satisfaction provided by the mother, we expect an interval where the child's response may appear, a basis for future responses or demands.

Finally, in the "paternal function" (PF) axis, the fourth one, we seek to follow-up the effects of this function on the child, which determines the weight of the mother's actions. We understand that the paternal function occupies, for the mother-child dyad, the place of a third instance, oriented by the social dimension. In her relationship with the child, a mother who must exercise the paternal function takes into account the parameters proposed by the culture to guide this relationship, as the paternal function is in charge of transmitting these parameters. The exercise of the paternal function on the mother-child dyad may have the effect of a symbolic separation between them, and will prevent her from considering her child as an "object" focused solely on her satisfaction. Therefore, the singularity of the child and his/her differentiation regarding the mother's body and words depend on this function.

\subsection{The initial IRDI research}

The main goal of the IRDI research was to check the power of the indicators for early detection of developmental problems in early childhood. The sample consisted of 727 children in the age brackets 0-4 incomplete months, 4-8 incomplete months, 8-12 incomplete months and 12-18 months, selected at random among those whose parents sought routine paediatric consultations at 11 healthcare service providers in nine Brazilian cities (Belém do Pará, Brasília, Curitiba, Fortaleza, Porto Alegre, Recife, Rio de Janeiro, Salvador and three healthcare centres in São Paulo). Clinical indicators were registered as present, absent and non-verified during the study. In this survey, it is the absence of indicators that suggests a risk to the child's development. Thus, when present, the IRDIs are indicators of 
development, and when absent, they point to a risk to development.

At the end of 18 months, 287 children showed 2 or more absent indicators (case group), and 440 showed 1 or 0 absent indicator (control group). Among the cases, 183 children were chosen by lot (64\%); out of whom 158 completed the study (a loss of $13.7 \%)$. Among the control children, 132 (30\%) were chosen by lot; out of whom 122 completed the study (a $7.5 \%$ loss).

When the children of this sub-sample reached the age of 3, they underwent a psychoanalytical diagnosis using a protocol created for this purpose: the Psychoanalytical Evaluation script AP3 (Lerner \& Kupfer, 2009) [17].

A statistical analysis showed that the IRDI as a whole has a greater capacity to predict developmental problems than to predict psychic risk. Additionally, it pointed out some indicators, either individually or in groups that are able to predict psychic risk or developmental problems.

\subsection{IRDI research: A new reach}

During the IRDI research, some researchers were asking themselves about the value of an instrument such as IRDI if it were to be employed in nurseries. The idea was not for it to be used by teachers, but by psychoanalytic psychologists as a guide for assessing and monitoring the psychic constitution of babies based on the teacher-baby dyad.

A new validation research project, now on an IRDI-based methodology, began in 2012. Thus, IRDI left the field of health and entered the field of education.

The problem the new research project faced was how to make schoolteachers assist the promotion of mental health in children, based on psychoanalysis, from early infancy.

\section{The IRDI methodology: an intervention in nursery schools}

The IRDI methodology is currently defined as a procedure for monitoring psychic development carried out by psychoanalysts in child education institutions by means of clinical indicators for early detection of developmental problems.

Given that early childhood includes the period from 0-3 years of age, and considering that the period 0-18 months is particularly important and decisive to the constitution of subjectivity [18], the research presented here focused only on children within this age range.

The IRDI methodology includes: 1) theoretical background on psychic constitution - target: nursery school teachers; 2) follow-up on teachers; 3) application of 31 clinical indicators for child development to evaluate and follow-up children in the 0-18 month age range under the care of teachers trained and monitored through the IRDI methodology. The study was carried out in two stages.

At stage 1, 107 teachers and 364 children were trained and monitored over 2012-13. At this stage, the aim was to evaluate the IRDI methodology efficiency as a tool for teachers training in following the psychic development of children from 0-18 months of age. Stage 2 (commencing 2014) will study 630 children (315 followed in Stage 1 as the Case Group, and 315 as the Control Group). The 630 children will be psychoanalytically evaluated at the age of 3 as to the likelihood of psychic risk, as per the AP3 (Psychoanalytical Evaluation at 3 years of age). The role played by the IRDI methodology in promoting mental health will be confirmed if the AP3 risk incidence reported by the Case Group is shown to be significantly lower than that of the Control Group.

In this paper, we are presenting the results of the first phase of the research, focusing especially on the results of teachers.

In this phase, a group of 27 researchers paid weekly visits to the nurseries researched over a period of 9 months. In their visits, they noted the presence or absence of the IRDIs. They regularly talked to the teachers about this, so as to draw their attention to babies with absent indicators. As a result, the indicators frequently became present.

The present, absent and not-checked clinical indicators were registered during the study. In this survey it is the absence of indicators that suggests a risk to the child's development. Thus, the IRDIs, when present, are indicators of development, and when absent, they point to a risk to development.

Next, we present in Table 1 the indicators adapted to a nursery environment and for the monitoring of the relationship of the teacher-baby dyad.

\subsection{Monitoring of teachers by means of the IRDI methodology}

Before verifying if using the IRDI methodology improves mental health, we needed to check if this improvement was related to the assimilation of its principles by the teachers. Therefore, the first phase 
Table 1. IRDI adapted to nursery teachers

\begin{tabular}{|c|c|}
\hline Age in months: & Indicators: \\
\hline $\begin{array}{l}0 \text { to } 4 \\
\text { incomplete } \\
\text { months: }\end{array}$ & $\begin{array}{l}\text { 1. When the child cries or screams, the teacher knows what the child wants. } \\
\text { 2. The teacher talks to the child in a style that is particularly addressed to the } \\
\text { child. ("motherese"). } \\
\text { 3. The child responds to motherese. } \\
\text { 4. The teacher proposes something to the child and waits for the response. } \\
\text { 5. Teacher and child exchange eye-contact. }\end{array}$ \\
\hline $\begin{array}{l}4 \text { to } 8 \\
\text { incomplete } \\
\text { months: }\end{array}$ & $\begin{array}{l}\text { 6. The child responds to nursery routines } \\
\text { 7. The child uses different signs to express different needs. } \\
\text { 8. The child demands the teacher's attention and waits some time for her } \\
\text { response. } \\
\text { 9. The teacher talks to the child using short sentences to address him/her. } \\
\text { 10. The child responds (sound, vocals) when the teacher or somebody else } \\
\text { addresses him/her. } \\
\text { 11. The child actively seeks contact with the teacher's eyes. } \\
\text { 12. The teacher supports the child's initiatives without stopping his/her efforts. } \\
\text { 13. The child asks for help from somebody else without remaining passive. }\end{array}$ \\
\hline $\begin{array}{l}8 \text { to } 12 \\
\text { incomplete } \\
\text { months: }\end{array}$ & $\begin{array}{l}\text { 14. The teacher understands that some demands from the child may be a way } \\
\text { to call her attention. } \\
\text { 15. During body care, the child actively attempts to play loving games with the } \\
\text { teacher. } \\
\text { 16. The child shows that he/she likes or dislikes something. } \\
\text { 17. Teacher and child share a private language. } \\
\text { 18. The child feels ill at ease with unknown people. } \\
\text { 19. The child has favourite objects. } \\
\text { 20. The child makes playful movements and faces. } \\
\text { 21. The child looks for the adult's look of approval. } \\
\text { 22. The child accepts semi-solid and varied foods. }\end{array}$ \\
\hline $\begin{array}{l}\text { From } 12 \text { to } 18 \\
\text { months }\end{array}$ & $\begin{array}{l}\text { 23. The teacher alternates between collective moments and moments where } \\
\text { she dedicates herself exclusively to the child. } \\
\text { 24. The child endures the teacher's brief absences well and reacts to longer } \\
\text { absences. } \\
\text { 25. The teacher offers toys as alternatives to the child's interests in the } \\
\text { teacher's body. } \\
\text { 26. The teacher no longer feels compelled to meet all of the child's demands. } \\
\text { 27. The child looks curiously at things that interest the teacher. } \\
\text { 28. The child likes to play with objects used by the teacher. } \\
\text { 29. The teacher starts to ask the child to say what he/she wants, not being } \\
\text { satisfied with gestures only. } \\
\text { 30. The teacher establishes small behaviour rules for the child. } \\
\text { 31. The child differentiates between objects belonging to teacher and to } \\
\text { him/her. }\end{array}$ \\
\hline
\end{tabular}


of the study was to find out whether this assimilation had occurred. This work presents the results of this evaluation.

In order to carry it out, pre and post tests were devised so as to be equivalent in what they measured.

The questionnaires contained 8 questions each and their formulations followed the following criteria:

a) questions 1 and 2 refer to indicators of axis 1 (supposition of demand);

b) questions 3 and 4 refer to axis 2 (establishment of demand);

c) questions 5 and 6 to axis 3 (presence/absence);

d) questions 7 and 8 to axis 4 (paternal function).

The aim of the tests was to evaluate the knowledge acquired during the course of the research.

\section{The IRDI in nursery schools: first phase results}

In 2012-2013, the pre and post-tests here presented were applied to two groups of teachers, a case group and a control group. The case group was composed of 56 teachers, monitored over 9 months by the IRDI Methodology, and the control group was a mirror of the case group but without the monitoring, although they did answer the same pre and post-tests.

Table 2 presents data obtained by applying the two types of tests to the case group and the control group.

Table 2. Comparison between answers of teachers from the case group and the control group in the pre-test and post-test

\begin{tabular}{|c|c|c|c|c|c|}
\hline \multicolumn{6}{|c|}{ CASE X CONTROLS } \\
\hline & \multirow{2}{*}{\multicolumn{2}{|c|}{$\begin{array}{l}\text { Case Group } \\
\text { PRE-TEST }\end{array}$}} & \multicolumn{2}{|c|}{ Control Group } & \\
\hline \multirow{2}{*}{ QUESTIONS } & & & \multicolumn{2}{|c|}{ PRE-TEST } & \multirow[t]{2}{*}{ VALUE } \\
\hline & \multicolumn{2}{|c|}{\begin{tabular}{l|l} 
CORRECT & PERCENTAGE
\end{tabular}} & CORRECT & PERCENTAGE & \\
\hline 1 & $28 / 56$ & $50 \%$ & $18 / 44$ & $40.9 \%$ & $\mathrm{p}=0.365$ \\
\hline 2 & $12 / 56$ & $21.4 \%$ & $4 / 44$ & $9 \%$ & $\mathrm{p}<0.095$ \\
\hline 3 & $25 / 56$ & $44.6 \%$ & $20 / 44$ & $45.4 \%$ & $\mathrm{p}=0.934$ \\
\hline 4 & $40 / 56$ & $66.7 \%$ & $31 / 44$ & $70.4 \%$ & $\mathrm{p}=0.915$ \\
\hline 5 & $41 / 56$ & $71.4 \%$ & $38 / 44$ & $86.3 \%$ & $\mathrm{p}=0.109$ \\
\hline 6 & $4 / 56$ & $7.1 \%$ & $6 / 44$ & $13.6 \%$ & $\mathrm{p}=0.283$ \\
\hline 7 & $8 / 56$ & $14.2 \%$ & $8 / 44$ & $18.1 \%$ & $\mathrm{p}=0.598$ \\
\hline 8 & $11 / 56$ & $19.6 \%$ & $19 / 44$ & $43.1 \%$ & $\mathrm{p}=0.015$ \\
\hline
\end{tabular}

Chi-squared test

\begin{tabular}{|c|l|l|l|l|l|}
\hline & \multicolumn{2}{|c|}{ Case Group } & \multicolumn{2}{c|}{ Control Group } & \\
\hline \multirow{2}{*}{ QUESTIONS } & \multicolumn{2}{|c|}{ POST TEST } & \multicolumn{2}{c|}{ POST TEST } & \multirow{2}{*}{ VALUE } \\
\cline { 2 - 5 } & CORRECT & \multicolumn{1}{|c|}{ PERCENTAGE } & CORRECT & PERCENTAGE & \\
\hline $\mathbf{1}$ & $53 / 56$ & $94.6 \%$ & $39 / 44$ & $88.6 \%$ & $\mathrm{p}=0.272$ \\
\hline $\mathbf{2}$ & $43 / 56$ & $76.7 \%$ & $13 / 44$ & $29.5 \%$ & $\mathrm{p}<0.001$ \\
\hline $\mathbf{3}$ & $55 / 56$ & $98.2 \%$ & $34 / 44$ & $77.2 \%$ & $\mathrm{p}=0.002$ \\
\hline $\mathbf{4}$ & $40 / 56$ & $71.4 \%$ & $17 / 44$ & $38.6 \%$ & $\mathrm{p}=0.001$ \\
\hline $\mathbf{5}$ & $46 / 56$ & $82.1 \%$ & $31 / 44$ & $70.4 \%$ & $\mathrm{p}=0.168$ \\
\hline $\mathbf{6}$ & $53 / 56$ & $94.6 \%$ & $38 / 44$ & $86.3 \%$ & $\mathrm{p}=0.139$ \\
\hline $\mathbf{7}$ & $10 / 56$ & $17.8 \%$ & $2 / 44$ & $4.5 \%$ & $\mathrm{p}=0.042$ \\
\hline $\mathbf{8}$ & $27 / 56$ & $48.2 \%$ & $10 / 44$ & $22.7 \%$ & $\mathrm{p}=0.009$ \\
\hline
\end{tabular}

Chi-squared test

Table 2 shows a comparison between the results of the case group and those of the control group so as to verify if the acquisition of knowledge by the case group could be attributed to the application of the IRDI methodology on the teachers. The chi-squared test showed that the difference in knowledge acquisition relative to questions $2,3,4,7$, and 8 was significant in the case group when it is compared to the control group. We can therefore conclude that the teachers from the case group gained more knowledge 
than the control group, which can be attributed to the monitoring with the IRDI methodology.

Questions 5 and 6 , relative to theoretical axis 3 (presence/absence), however, were not well assimilated. In this axis, we can hypothesise that the teachers should have been acting more like mothers, but they resist assimilating these behaviours because they do not want to be accused of taking the mother's place.

Question 1 was not well assimilated, probably for the same reason. Both in the pre and post-tests, question 1 asks the teacher if she is allowed to talk to the children in a particular manner - using motherese - , but the teachers show that they fear they will overstep the mark in some way. However, these actions are vital for children in nursery schools, because they give them self-confidence and the feeling that home and nursery are contiguous.

These results show that greater effort will have to be made regarding transmitting the underpinnings of this theoretical axis. However, the absence of assimilation of this axis does not jeopardise the teachers' assimilation, which can be considered satisfactory, as three out of the four axes were understood by them.

\subsection{Additional results}

In a sample of 124 children, $30 \%$ of them had A to $\mathrm{P}$ changes (Absent to Present Indicators) after two months of follow-up with the IRDI protocol. This result was considered to be significant, although still partial. It points to the fact that monitoring teachers and the assimilation of knowledge shown above can produce real changes in children's behaviours. In this first phase of the research, we can already envisage the IRDI's capacity to reducing signs of risk of psychic problems in the first 18 months of a child's life.

\section{Qualitative Results}

During the first phase of the research, the field researchers met with the research coordinators on a weekly basis in order to discuss the stories they were collecting and to raise any theoretical questions relative to the participation of the nurseries in the constitution of the "baby-subjects".

Although the aim of the research is to find statistical and quantitative bases for the hypotheses formulated, much qualitative data were extracted from the researchers' daily experience in the nurseries, which were then discussed in the research meetings. For psychoanalysis, the dimensions of the singular and of the constitutive markers that are built for each child in every step are particularly important. Hence, there follows a small vignette, which illustrates how the IRDI methodology operates in nurseries:

Vini is a 16-month-old baby who does not worry his educators. He plays a lot with the other children and talks to them, inviting them to play ball and fighting over toys with them. He eats well, sleeps well and follows the nursery's routines.

However, monitoring with the IRDI methodology reveals that he constantly avoids contact with the educators. When he falls down and hurts himself and a teacher approaches, he stops crying and distances himself before he can be soothed. IRDIs 23, 24, 25 a and b, 27, 28 and 29 are absent. In the previous band, there are indicators that should be present, but are absent - indicators 15, 20 and 21 (see appendix 1). When he is changed, he regularly falls asleep. He makes no request to the adults to get down from his high chair while he waits after eating and usually falls asleep, often being the last one to be taken to his cot. Considered in the collective, but not in that which is specific to him, Vini does not demand exclusive attention.

It was in this context that the researcher proposed a discussion with the educators. In this case, the intervention aimed to strengthen the educators' mothering function, leading them to deal with him, talk to him and address him in a particular fashion. Two weeks later, the researcher found quite a different dynamic. Vini cried more and was more demanding, and was now constantly hanging on to one of the teachers' legs. But on the following week, he was crying less and playing calmly. He sought the educator's protection at times when he seemed frightened by one of the children. He also asked her to change cots and heard her reply: "How smart! You already know how to ask for what you want!"

\section{Conclusions}

Until this moment, results point out that: 1) The IRDI Methodology improves teachers' capacity of accompanying the mental health development of children under their care. Comparing pre and posttests, teachers showed differences between what they used to see before and after the IRDI methodology follow-up. 2) IRDI methodology significantly reduces the presence of risk signals, which points to its capacity to reduce the risks of mental problems developing.

We hope that the second phase of the study shall provide additional data so as to show how important care of babies that takes their subjectivity into account is. 


\section{Acknowledgments}

We would like to thank FAPESP for their support and research funding, the initial group of researchers who carried out the research, and the current group, who dedicated themselves to going to the nurseries and collected data that turned out to be so significant.

\section{References}

[1] J.P. Shonkoff (Ed.) and D.A. Phillips (Ed.) From neurons to neighborhoods: The science of early childhood development. National Research Council and Institute of Medicine. National Academy Press, Washington, DC, 2000.

[2] Ministério do Planejamento, Orçamento e Gestão. Instituto Brasileiro de Geografia e Estatística. Síntese de Indicadores sociais: uma análise das condições de vida da população brasileira. Estudos e Pesquisas - Informação Demográfica e Socioeconômica. IBGE, Rio de Janeiro, 2010.

[3] H.R. Bird, Epidemiology of childhood disorders in a cross-cultural contexto, J Child Psychol Psychiatry, 37(1), ACAMH, London, 1996, pp. 35-49.

[4] B.W. Fleitlich and R. Goodman. Epidemiologia. Rev Bras Psiquiatr, 22(Suppl2), Associação Brasileira de Psiquiatria, São Paulo, 2000, pp. 2-6.

[5] M.C. Laznik, A voz como primeiro objeto da pulsão oral, Estilos da Clínica. Revista sobre a infância com problemas, 5(8), IPUSP, São Paulo, 2000, pp. 80-93.

[6] G. Crespin, Paroles de tout-petits. À l'écoute des enfants en creche, Albin Michel, Paris, 2006.

[7] G. Crespin, Traitements des troubles du spectre autistique, Érès, Paris, 2012.

[8] L.M.F. Bernardino, A abordagem psicanalítica do desenvolvimento infantil e suas vicissitudes. In L. Bernardino (Ed.). O que a psicanálise pode ensinar sobre a criança, sujeito em constituição, Escuta, São Paulo, 2006, pp. 19-41.

[9] R.M.M. Mariotto, Cuidar, Educar e Prevenir: as funções da creche na subjetivação de bebês, Escuta, São Paulo, 2009.

[10] A. K. de O. Costa; N. A. Z. Cruz; V. L. da Silva, Saúde Mental nas Creches: A Compreensão de Educadores e a Importância de se trabalhar a Promoção da Saúde em Escolares, Anais do $2^{\circ}$ Congresso Brasileiro de Ludodiagnóstico, 2(2), Escola Paulista de Psicologia Avançada, São Paulo, 2011, available at: http://psi21.com.br/ojs/index.php/CBL/article/view/162. Accessed on: 2013-06-17.
[11] M.C. Kupfer, A.N. Jerusalinsky, L.M. Bernardino, D. Wanderley, P.S.B. Rocha et al., Valor preditivo de indicadores clínicos de risco para o desenvolvimento infantil, Lat. Am. Journal of Fund. Psychopath. Online, 6(1), AUPF, São Paulo, 2009, pp.48-68.

[12] S. Freud. Três Ensaios para uma Teoria Sexual. Trad. J. Salomão. Rio Janeiro: Imago, 1996. Edição Standard Brasileira das Obras Psicológicas Completas de Sigmund Freud, vol. 7, p.29-66. First edition 1905.

[13] S. Freud. Além do Princípio do Prazer. Trad. J. Salomão. Rio Janeiro: Imago, 1996. (Edição Standard Brasileira das Obras Psicológicas Completas de Sigmund Freud, vol. 18, p.11-76). First edition 1920.

[14] S. Freud, S. A Dissolução do Complexo de Édipo. Trad. J. Salomão. Rio Janeiro: Imago, 1996. Edição Standard Brasileira das Obras Psicológicas Completas de Sigmund Freud, vol. 19, p.189-199. First edition 1924.

[15] S. Ferreira. A interação mãe-bebê: primeiros passos. In D.B. Wanderley (org.). Palavras em torno do berço: intervenções precoces bebê e família. Salvador: Ágalma, 1997.

[16] M.C.Laznik. A voz da sereia: o autismo e os impasses na constituição do sujeito. Salvador: Ágalma, 2004.

[17] R. Lerner \& M.C. Kupfer. (org) Psicanálise com crianças: clínica e pesquisa. FAPESP/Escuta, São Paulo, 2008.

[18] A. Guedenay, A.S. Mintz and R. Dugravier. Risques développementaux chez le nourrisson de la naissance à 18 mois, Psychiatrie/Pedopsichiatrie, 17 (195- A-20), Elsevier Masson, Paris, 2007, pp 1-6. 